\title{
Economic viability and profitability assessments of WECS
}

\author{
Mohammed Kdair Abd \\ Department of Electrical Engineering, University of Technology, Iraq
}

\begin{tabular}{l} 
Article Info \\
\hline Article history: \\
Received Apr 5, 2019 \\
Revised Oct 12, 2019 \\
Accepted Oct 22, 2019 \\
\hline
\end{tabular}

\section{Keywords:}

Capital cost

HOMER

Renewable energy

WECS

Wind speed

\begin{abstract}
Technical and technological advances in alternative energy sources have led many countries to add green energy to their power plants to reduce carbon emissions and air pollution. At present, many electricity companies are looking to use alternative sources of energy because of high electrical energy prices. Wind energy is more useful than many renewable energies such as solar, heat, biomass, etc. The Wind Energy Conversion System (WECS) is a system that converts the kinetic energy of the wind into electrical energy to feed the known loads. WECS can be found in a variety of technology. Climate change and load demand are essential determinants of WECS optimization modelling. In this paper, proposed a strategy focused primarily on economic analysis WECS. The strategy based on a weather change to find the optimal designing and modelling for four different types of WECS using HOMER software. Finally, several criteria were used to determine which type of WECS was the most profitable investment and less payback period.
\end{abstract}

Copyright $@ 2020$ Institute of Advanced Engineering and Science. All rights reserved.

Corresponding Author:

Mohammed Kdair Abd, Department of Electrical Engineering, University of Technology, Al-Sina'a Street, 10066 Baghdad, Iraq. Email: 30098@uotechnology.edu.iq

\section{INTRODUCTION}

Renewable energy has gained considerable attention around the world. They are obtained naturally and directly in a short period such as sun or heat, wind, hydropower, biomass, geothermal energy and tidal energy. Among many renewable energies, wind power is one of the most useful energies. WECS, which transforms the wind's potential energy into electrical energy, where wind power plays a vital role in the generation and growth of electric power. As well as the users of advanced technologies have made the world moving towards the use of wind power widely [1]. The different wind energy conversion systems are compared based on power consumption, category, cost, efficiency and control. Reference [2] focuses on a comprehensive review to compare the performances of electric generators. The electrical power generated from WECS is works differently as it depends on the wind speed and location-specific. Wind energy is random and unstable energy that increases with increasing wind speed. The [3] proposed Simulation the behaviour of the wind speed using Weibull distribution and calculated power typical of the wind turbine. Controlling the maximum wind energy captured by a wind turbine indicates that the wind turbine operates at its maximum efficiency.

Several works have also been used different techniques to control wind speed to ensure continuity of generation. References [4, 5], proposed the fuzzy adaptive control model to control WECS. However, traditional adaptive control requires knowledge of the mathematical, pattern and structure of the model. The efficient and safe operation of the power system requires novel tools and methods to solve the Optimal Power Flow (OPF) problem in wind farms due to the random nature of wind energy. A Genetic Algorithm developed for Economic Dispatch and OPF. It applied to the WECS [6]. Wind speed data analysis used in the installation of WECS in Algeria is proposed in [7] study the difference between daily and seasonal wind speed at 10 and $50 \mathrm{~m}$ above the ground level and using wind speed data for almost ten years. WECS 
connected to the grid provides interesting control requirements, due to the intrinsic-nonlinear characteristics of the wind turbines and electric generators.

The control theory of predictive model control (MPC) was proposed to control the doubly-fed induction generator that controls the active and reactive power exchanged between the stator and grid [8-12]. Climate changes or grid faults affect wind power generation. In the case of a fault, the voltage at the Point of Common-Coupling (PCC) will be reduced to $80 \%$, and the rotor-speed of induction generators is unstable. These faults are controlled by adding the UPFC, which is designed to increase the voltage on the terminals of the WECS to reduce the electric power and torque during the fault period [13]. The improved efficiency control for WECS by using Minimum Ohmic Loss (MOL) controller in order to minimise the generator resistive-loss that accomplished by adjusting the d-axis stator current according to torque-conditions. The effectiveness of MOL controller is successful with two types of Maximum Power Point Tracking (MPPT) controllers to get to maximise the Wind Turbine (WT) output power [14, 15].

Reference [16, 17], proposed a stochastic model that captures the uncertainties in the system load at the wind generator bus. The index was used of reliability and applied on a simple model of a grid-connected WECS. The index of reliability is as the Mean First Passage Time (MFPT), the time taken for the system to leave its stability zone. In Implementing the Capacity Credit (CC) approach is proposed in [18] to investigate the economics of individual WECS projects. It has been taken the electricity consumption tariff as an evaluation tool to highlight the impact of economic value and benefits of CC on WECS projects. In reference [19], propose choice the best possible method between Variable speed/Constant Frequency and Constant Speed/Constant Frequency of WECS for speed-control which comprises speed controller, actuator perfect and the linearised turbine model which can be used to stabilise the frequency through speed-control.

This paper studying and analysis the problem of the unavailability and stability of the wind during the year and places, due to there is no wind blowing at fixed times and constant speed. The considered is the investment cost of any project is expensive. Therefore it must increase the renewables supply penetration and reducing the cost of energy, fuel consumption and storage requirements. This paper has two steps: Firstly, proposed the design of WECS optimal configuration. For simulated, we took four types of WECS models. Secondly, study the technical, economic and profitability calculations on the optimal configuration of WECS using HOMER software. Economic viability and profitability assessments for any renewable energy system is essential before starting planning to invest any electrical power system.

\section{WIND ENERGY CONVERSION SYSTEM (WECS)}

Wind energy works mainly on moving wind turbines and producing kinetic energy, which the WECS converts to electrical energy. The difficulty of regulating primary wind energy, it makes it unreliable to provide continuous demand for energy, so a smart computer-based system has been installed. These intelligent structures work on the turbocharged operation, improved wind turbine performance, fault detection and thus increasing the conversion of energy. A wind turbine can be intended for constant speed or mutable speed operation. Variable-speed wind turbines can produce a higher energy rate from $8 \%$ to $17 \%$ compared with their fixed speed counterparts. Also, they require power converters to provide a constant voltage and frequency for their loads. Most turbine manufacturers have select for lowering gears between the low-speed turbine rotor and the high-speed three-phase generators. The benefits of the connected generator coupled with the rotor of a wind turbine directly, give high reliability, low maintenance and low cost for some turbines [20].

\section{METHODOLOGY}

The methodology used in this paper for simulation and modelling purposes is Renewable Energy (HOMRE) software. The proposed model is consists of WT, load, generator, power converter and batteries. The data of average wind speed and load data are collected and analysing ever monthly in a year. In this paper, wind speed and load data using are the standard data collected from the HOMRE [21, 22], described as follows:

\subsection{Wind speed data}

For the best performance of the wind turbine, there must be winds ranging from 4 to 8 (m/s). If the average of the wind speed is not stable and less than 4 , it will lead to a failure to ensure stable electricity generation. We can note from Figure 1, and winds are abundant in January $(8 \mathrm{~m} / \mathrm{s})$, February $(7.5 \mathrm{~m} / \mathrm{s})$ and December $(7.5 \mathrm{~m} / \mathrm{s})$. The Weibull value equals 1.95 . Also, the value of the autocorrelation factor equal to 0.893 and diurnal pattern strength equal to 0.283 [23]. 


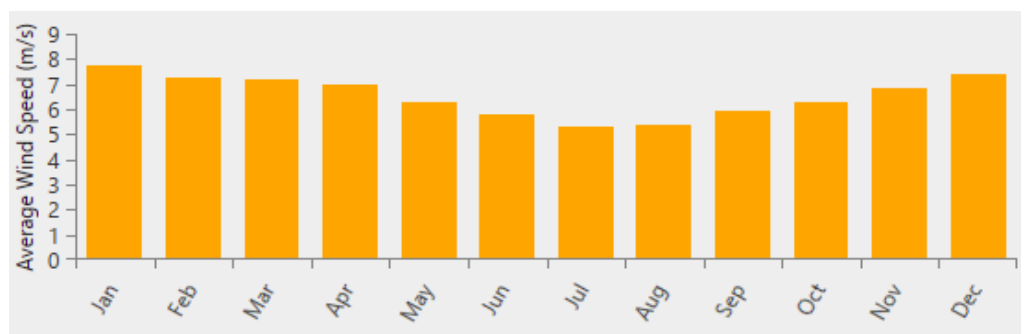

Figure 1. Rate monthly wind speed

\subsection{Load data}

The load data is the data which have 8760 values appear the average electrical consumption, for each $\mathrm{kW} /$ hour of the year. It is possible to draw an average load for hourly, daily, monthly and annually. The histogram of the load data during 12 months of a year, as shown in Figure 2. The daily average of the load is $170 \mathrm{kWh} /$ day, and the annual peak load is $21.02 \mathrm{~kW}[23]$.

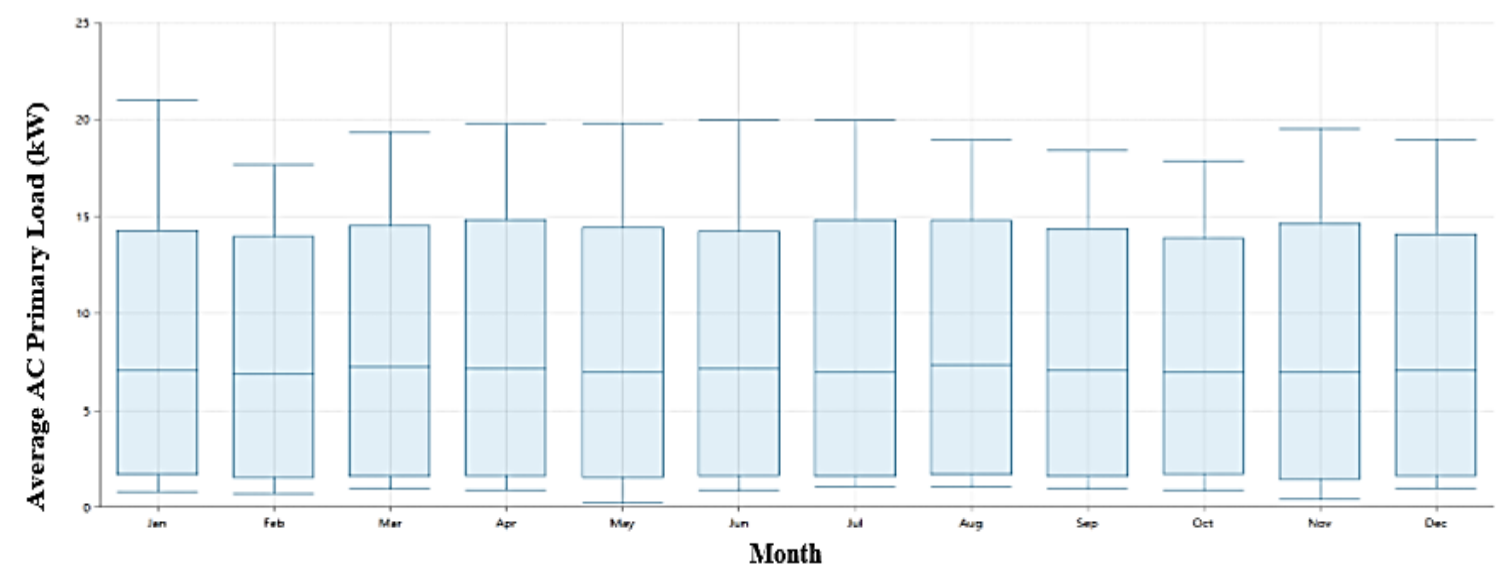

Figure 2. Rate monthly load profile

\section{THE PROPOSED MODEL}

\subsection{Wind turbine data}

In this paper, proposed four models of WECS, which are based on wind speed and load data inputs. The WT is the main part of this model, which must meet the load demand. The process of entering information uses the same wind speed data for all modelling systems with the addition of costs. These costs include the capital cost, maintenance, replacement and operation. The input data of WECS are labelled in Table 1 .

\subsection{Power converter and batteries data}

Wind speed varies during the year; it causes unstable in the electric power supply will continue. The addition of battery storage facilities to the system is essential, which works on charging and discharging to compensate for the shortage of energy generated. The inverter is used to convert wind energy that produces electrical power DC to electrical power AC. The Homer program is applied to simulate four models of WECS and calculates the variations of all designs based on the inputs provided and system simulation. Table 1 briefly describes inputs data.

\subsection{Generator data}

Each system built by Homer software needs to one generator. The generator is working as a backup source to ensure that the load is supplied with electrical power continuously. The type, cost and lifetime of the generator shown in Table 1. 
Table 1. Input data of the HOMER for the proposed model [23-26]

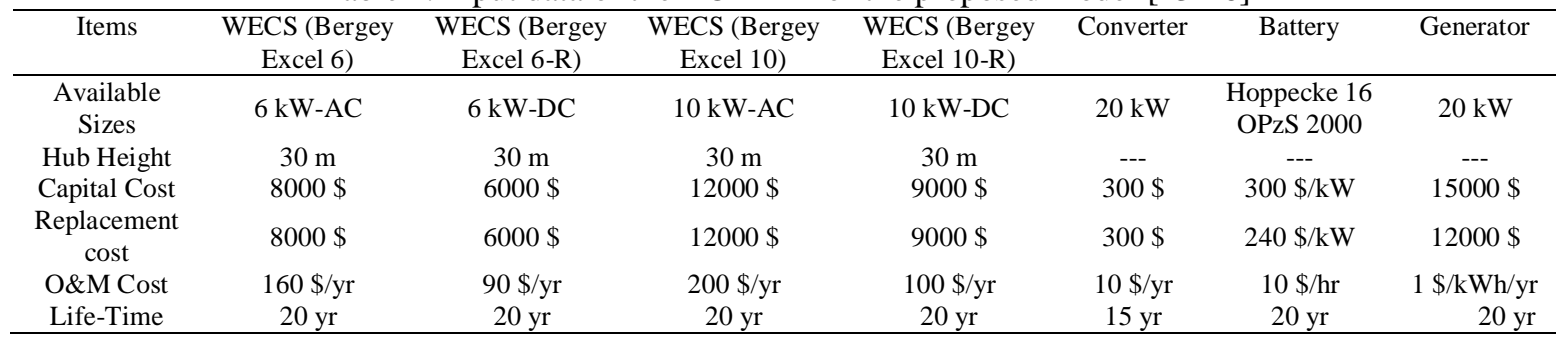

\subsection{The proposed algorithm}

HOMER software is simulation and optimisation to produce the best configuration and suitable system with an operating system guarantee of satisfying the constraints. In this part of the paper, the assessment criteria will be specified to find out which type of WECS models were more employment, exploitation and profitability. Mathematically, the simulation and process of the modelling are written as below in Sim.

Sim

Step1. Start.

Step2. Input the wind speed data and load data.

Step3. Select all the components which are going to use in the models (the type of WT, generator, number of battery and converters).

Step4. Set initial data of WT, generator, number of battery and converters such as initial cost, capital cost, replacement cost, and so on.

Step5. After entering all the information, the Homer software uses the following equations [23], [27]:

$$
\begin{aligned}
& \text { Net Present Cost }(\boldsymbol{N P C})=\frac{\boldsymbol{T A C}}{\operatorname{CRF(i,z)}}=\frac{C_{\text {acap. }}+\sum_{i=1}^{m} C_{\boldsymbol{O M}, i}+C_{f}+\sum_{j=1}^{m} C_{R, j}}{\operatorname{CRF(i,z)}} \\
& \text { Capital Recovery Factor }(C R F(i, z))=\frac{i(1+i)^{z}}{(1+i)^{z}-1} \\
& \text { Real discount rate }(i)=\frac{i^{\prime}-f}{1+f} \\
& \text { Cost of Energy }(C O E)=\frac{T A C-C_{\text {boiler }} H_{\text {served }}}{E_{\text {served }}}
\end{aligned}
$$

where: $T A C$ is Total Annualized Cost, $m$ is the number of years, $f$ is expectant inflation-rate, $C_{\text {boiler }} H_{\text {served }}$ is the cost of serving the thermal load and $E_{\text {served }}$ is total electric load-served.

Step6. Compute and test the results. Such as the output power of the WECS, charging or discharging the batteries, load demand and all types of the costs.

Step7. Go to step 5 to compute the system again in order to simulate the optimal system configuration.

Step8. Selected the best configuration according to the costs.

Step9. Determine $N P V, I R R$ and $P P$ required to economic viability and profitability assessments to recover the initial amount invested in any power system. It can be expressed as follows:

$$
\begin{aligned}
& \text { Net Present Value }(N P V)=-Y_{o}+\frac{Y_{1}}{(1+i)^{1}}+\frac{Y_{2}}{(1+i)^{2}}+\ldots \ldots+\frac{Y_{x}}{(1+i)^{x}} \\
& 0=Y_{o}+\frac{Y_{1}}{(1+I R R)^{1}}+\frac{Y_{2}}{(1+I R R)^{2}}+\ldots \ldots+\frac{Y_{K}}{(1+I R R)^{K}} \\
& \text { Payback Period }(P P)=-\frac{\ln \left(1-\frac{P L E C * C I}{A R S E-m C I}\right)}{\ln (1+P L E C)}
\end{aligned}
$$

where: $Y_{O}$ is an initial investment, $Y x$ is cash-flow, $x$ is the number of years, and IRR is Internal Rate of Return. $Y_{K}$ is future present-value, $P L E C$ is the Price of Local Electricity Cost, $C I$ is Initial Capital, and ARSE is Annual Return Sales of the Electricity.

Step10. Comparison of the results.

Step11. Print the results.

Step12. Stop. 


\section{SIMULATION AND RESULTS}

\subsection{The optimal type of WECS}

The proposed of four hybrid models are shown in Figure 3 (a-d), has been designed and simulated with the use of HOMER to find the optimal type of WECS. Four types of WECS used as follows: Firstly type, WECS (6kW-AC), Second type, WECS (6kW-DC), the third type, WECS (10kW-AC) and fourthly type, WECS (10kW-DC).

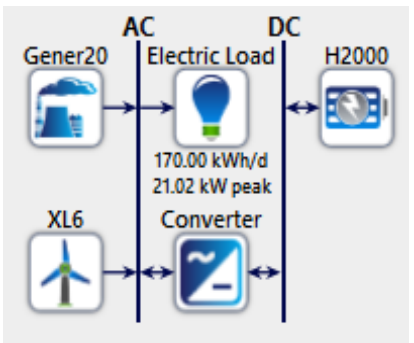

(a)

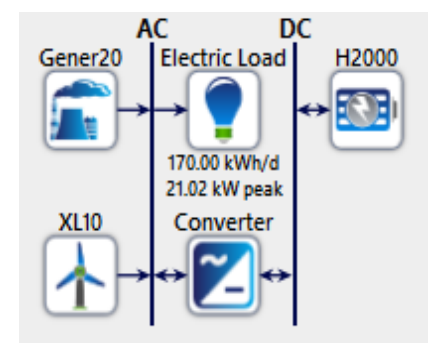

(c)

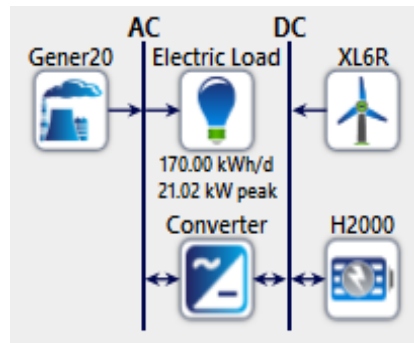

(b)

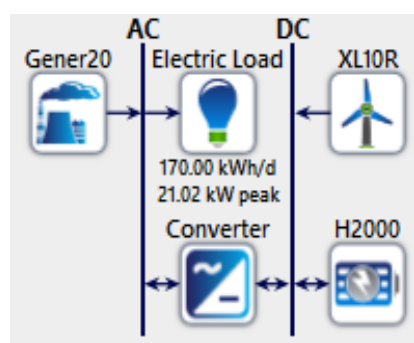

(d)

Figure 3. The different schematic configuration in HOMER, (a) Schematic of WECS (6kW-AC),

(b) Schematic of WECS (6kW-DC), (c) Schematic of WECS (10kW-AC),

(d) Schematic of WECS (10kW-DC)

HOMER ranks the configuration based on $C O E$ and $N P C$ values. The initial capital cost, $C O E$ and $N P C$ that needs to be analysed and focus in all analyses. According to the result shown in Figure $4(\mathrm{a}, \mathrm{b})$, the optimal configuration for both modelling is WECS (6kW-AC). The NPC is $\$ 104,834$, while the initial capital cost for the WECS (6kW-AC) is $\$ 78,305$. Moreover, the COE is $\$ 0.147$, and total operating cost is $\$ 2,313 / \mathrm{yr}$. The increase of initial capital cost value is due to the use of a large number of wind generators which that not practical over time.

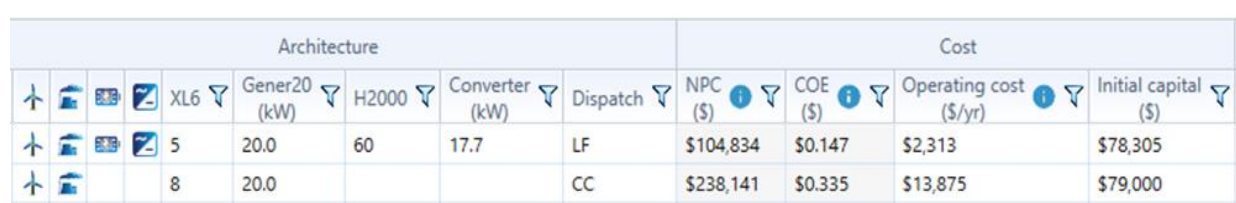

(a)

\begin{tabular}{|c|c|c|c|c|c|c|c|c|}
\hline \multicolumn{5}{|c|}{ Architecture } & \multicolumn{4}{|c|}{ Cost } \\
\hline 个二四 XLER $\nabla$ & $\begin{array}{c}\text { Gener } 20 \\
(\mathrm{~kW})\end{array}$ & H200O P & $\begin{array}{c}\text { Converter } \nabla \\
(\mathrm{kW})\end{array}$ & Dispatch $\nabla$ & $\begin{array}{l}\mathrm{NPC} \\
(5)\end{array}$ & ${ }_{(5)}^{\mathrm{COE}} \oplus \nabla$ & $\begin{array}{c}\text { Operating cost } \\
(S / y r)\end{array}$ & $\begin{array}{c}\text { Initial capital } \nabla \\
\text { (5) }\end{array}$ \\
\hline 小的 1 & 20.0 & 24 & 11.3 & $\mathrm{CC}$ & $\$ 206,349$ & 50.290 & $\$ 15,235$ & $\$ 31,600$ \\
\hline - & 20.0 & 18 & 10.7 & $\mathrm{cc}$ & $\$ 269,954$ & $\$ 0.379$ & $\$ 21,477$ & $\$ 23,613$ \\
\hline
\end{tabular}

(b)

Figure 4. Optimal configuration of the power system $(6 \mathrm{~kW})$, (a) WECS (6kW-AC), (b) WECS (6kW-DC) 
In the same time of the simulation, Figure $5(\mathrm{a}, \mathrm{b})$ show the optimization result of WECS $(10 \mathrm{~kW}-\mathrm{AC})$ and WECS (10kW-DC). According to the result, the optimal configuration for both modelling is WECS $(10 \mathrm{~kW}-\mathrm{AC}$ ). We can see the $N P C$ is $\$ 166,789$, while the initial capital cost is $\$ 37,564$. Also, the $C O E$ is $\$ 0.234$, and total operating cost value is $\$ 11,216 / y r$. The increase of initial capital cost value because of the increased number of batteries which need more maintenance and replacement over time compared with WECS (10kW-DC).

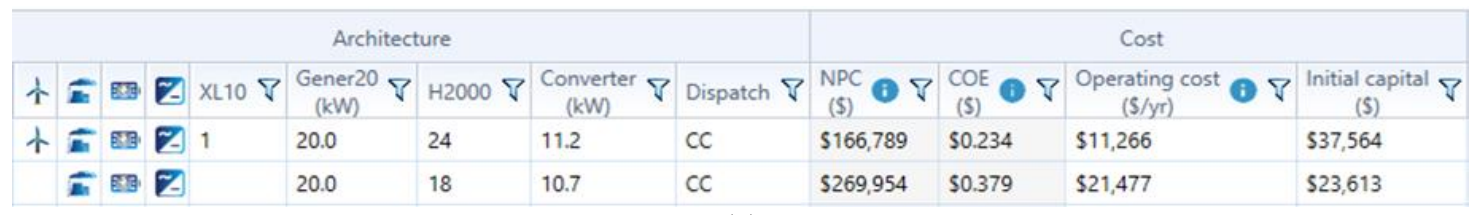

(a)

\begin{tabular}{|c|c|c|c|c|c|c|c|c|c|c|}
\hline \multicolumn{7}{|c|}{ Architecture } & \multicolumn{4}{|c|}{ Cost } \\
\hline t & E & E & $\begin{array}{c}\text { Gener } 20 \text { P } \\
(\mathrm{kW})\end{array}$ & H2000 ₹ & $\begin{array}{c}\text { Converter } \nabla \\
(\mathrm{kW})\end{array}$ & Dispatch $\nabla$ & $\left.\begin{array}{l}\mathrm{NPC} \\
(\$)\end{array}\right]$ & $\begin{array}{l}\mathrm{COE} \\
(\$)\end{array}$ & $\begin{array}{c}\text { Operating cost } \\
(\$ / y r)\end{array}$ & $\begin{array}{l}\text { Initial capital } \nabla \\
\text { (\$) }\end{array}$ \\
\hline r & E & 잘 1 & 20.0 & 18 & 14.2 & $\mathrm{CC}$ & $\$ 174,152$ & $\$ 0.245$ & $\$ 12,248$ & $\$ 33,672$ \\
\hline & E & 태졍 & 20.0 & 18 & 10.7 & $\mathrm{CC}$ & $\$ 269,954$ & $\$ 0.379$ & $\$ 21,477$ & $\$ 23,613$ \\
\hline
\end{tabular}

Figure 5. Optimal configuration of the power system (10kW), (a) WECS (10kW-AC),

(b) WECS (10kW-DC)

Table 2 shows the overall simulation and comparison results for WECS (6kW-AC), WECS (6kWDC), WECS (10kW-AC) and WECS (10kW-DC). The results present a cash flow summary for each component of the models. For WECS $(6 \mathrm{~kW}-\mathrm{AC})$, the total cost of batteries and converter systems is very high because of the large number of using the wind turbine. For WECS (6kW-DC), the generator consumes more fuel, the NPC is higher, and the initial capital cost is high. Some of the results shown that the capital cost is low, with a large $C O E$ value or vice versa. The indicates that the $C O E$ value or capital cost index is insufficient in the selection of the optimal WECS.

Table 2. Cash flow summary and comparison results

\begin{tabular}{cccccc}
\hline Items & $\begin{array}{c}\text { Total cost } \\
\text { of WT }(\$)\end{array}$ & $\begin{array}{c}\text { Total cost of the } \\
\text { generator }(\$)\end{array}$ & $\begin{array}{c}\text { Total cost of } \\
\text { the battery }(\$)\end{array}$ & $\begin{array}{c}\text { Total cost of the } \\
\text { converter }(\$)\end{array}$ & $\begin{array}{c}\text { Total cost of } \\
\text { the system }(\$)\end{array}$ \\
\hline WECS (6kW-AC) & 49,175 & 24,359 & 24,881 & 6,415 & 104,833 \\
WECS (6kW-DC) & 9,032 & 178,773 & 16,431 & 4,111 & 206,348 \\
WECS (10kW-AC) & 14,293 & 133,225 & 15,201 & 4,968 & 166,789 \\
WECS (10kW-DC) & 10,146 & 145,071 & 13,768 & 5,165 & 174,152 \\
\hline
\end{tabular}

\subsection{Economic viability and profitability of WECS}

The optimal economic viability and profitability of WECS depend on three assessment criteria are $N P V, I R R$ and $P P$. The $N P V$ is an important criterion for profitability assessment of the WT systems; It is calculated using equation 5. Table 3 shows that the cash flow of each year for four types of WECS and assuming the lifetime for components of the system is 20 years. In Table 3, the cash flow of the four types of WECS changes each year due to changes in energy consumption, wind speed, maintenance and replacement of unemployed parts. Period 0 is the year in which the initial investment of the system occurs. Also, Table 4 shows a comparison between four types of WECS based on the three evaluation criteria.

The second important criterion is IRR; it is an important criterion for economic assessment when analysing the profitability of wind turbine systems project. The IRR calculated using (6). From Table 4, the IRR value for WECS $(6 \mathrm{~kW}-\mathrm{AC})$ is $41.5 \%$, WECS $(6 \mathrm{~kW}-\mathrm{DC})$ is $87.5 \%$ while, $80.0 \%$ for WECS $(10 \mathrm{~kW}-$ AC) and WECS (10kW-DC) is $91.8 \%$. The results show that using the WECS (10kW-DC) is the best choice because the $I R R$ value is highest. Finally, the $P P$ criterion is used to calculate and find the accurate period for the cumulative cash flow of the system to payback value of the initial investment. The $P P$ value for WECS $(6 \mathrm{~kW}-\mathrm{AC})$ is 2.44 , WECS (6kW-DC) is 1.27 while, 1.34 for WECS (10kW-AC), and WECS (10kW-DC) is 1.22. From cumulative cash flow values, the $P P$ schema was plotted, as shown in Figure 6. The graph shows that using WECS $(10 \mathrm{~kW}-\mathrm{DC})$ is the best choice because the $P P$ value is lowest. 
Table 3. Cash flow for four types of WECS

\begin{tabular}{ccccc}
\hline Period $(\mathrm{yr})$ & NPV $(6 \mathrm{~kW}-\mathrm{AC})$ & NPV $(6 \mathrm{~kW}-\mathrm{DC})$ & NPV $(10 \mathrm{~kW}-\mathrm{AC})$ & NPV $(10 \mathrm{~kW}-\mathrm{DC})$ \\
\hline 0 & $-\$ 50,357$ & $-\$ 16,600$ & $-\$ 22,564$ & $-\$ 18,672$ \\
1 & $\$ 21,914$ & $\$ 10,582$ & $\$ 13,783$ & $\$ 13,147$ \\
2 & $\$ 33,914$ & $\$ 22,582$ & $\$ 25,783$ & $\$ 25,147$ \\
3 & $\$ 21,914$ & $\$ 10,582$ & $\$ 13,783$ & $\$ 13,147$ \\
4 & $\$ 33,914$ & $\$ 22,582$ & $\$ 25,783$ & $\$ 25,147$ \\
5 & $\$ 21,914$ & $\$ 10,582$ & $\$ 13,783$ & $\$ 13,147$ \\
6 & $\$ 33,914$ & $\$ 10,582$ & $\$ 25,783$ & $\$ 20,827$ \\
7 & $\$ 33,914$ & $\$ 16,822$ & $\$ 25,783$ & $\$ 13,147$ \\
8 & $\$ 21,914$ & $\$ 10,582$ & $-\$ 3,977$ & $\$ 13,147$ \\
9 & $\$ 33,914$ & $\$ 22,582$ & $\$ 25,783$ & $\$ 25,147$ \\
10 & $\$ 21,914$ & $\$ 10,582$ & $\$ 13,783$ & $\$ 13,147$ \\
11 & $\$ 33,914$ & $\$ 10,582$ & $\$ 25,783$ & $\$ 25,147$ \\
12 & $\$ 33,914$ & $\$ 22,582$ & $\$ 25,783$ & $\$ 1,147$ \\
13 & $\$ 21,914$ & $\$ 10,582$ & $\$ 13,783$ & $\$ 25,147$ \\
14 & $\$ 33,914$ & $\$ 16,822$ & $\$ 25,783$ & $\$ 8,876$ \\
15 & $\$ 18,157$ & $\$ 7,182$ & $-\$ 1,581$ & $\$ 25,147$ \\
16 & $\$ 33,914$ & $\$ 10,582$ & $\$ 20,023$ & $\$ 13,147$ \\
17 & $\$ 21,914$ & $\$ 10,582$ & $\$ 13,783$ & $\$ 20,827$ \\
18 & $\$ 33,914$ & $\$ 22,582$ & $\$ 25,783$ & $\$ 13,147$ \\
19 & $\$ 33,914$ & $\$ 22,582$ & $\$ 25,783$ & $\$ 23,571$ \\
20 & $\$ 20,578$ & $\$ 10,131$ & $\$ 16,648$ & \\
\hline
\end{tabular}

Table 4. The economic comparison of the summarisation results

\begin{tabular}{ccccc}
\hline Assessments criteria & WECS (6kW-AC) & WECS (6kW-DC) & WECS (10kW-AC) & WECS (10kW-DC) \\
\hline Present worth (\$) & 253,960 & 152,444 & 192,004 & 184,641 \\
Annual worth (\$) & 22,141 & 13,291 & 16,740 & 16,098 \\
Return on investment (\%) & 38.7 & 83.0 & 77.4 & 89.3 \\
Internal rate of return (\%) & 41.5 & 87.5 & 80.0 & 91.8 \\
Payback Period (yr) & 2.44 & 1.27 & 1.34 & 1.22 \\
Discounted payback (yr) & 2.78 & 1.33 & 1.41 & 1.28 \\
\hline
\end{tabular}

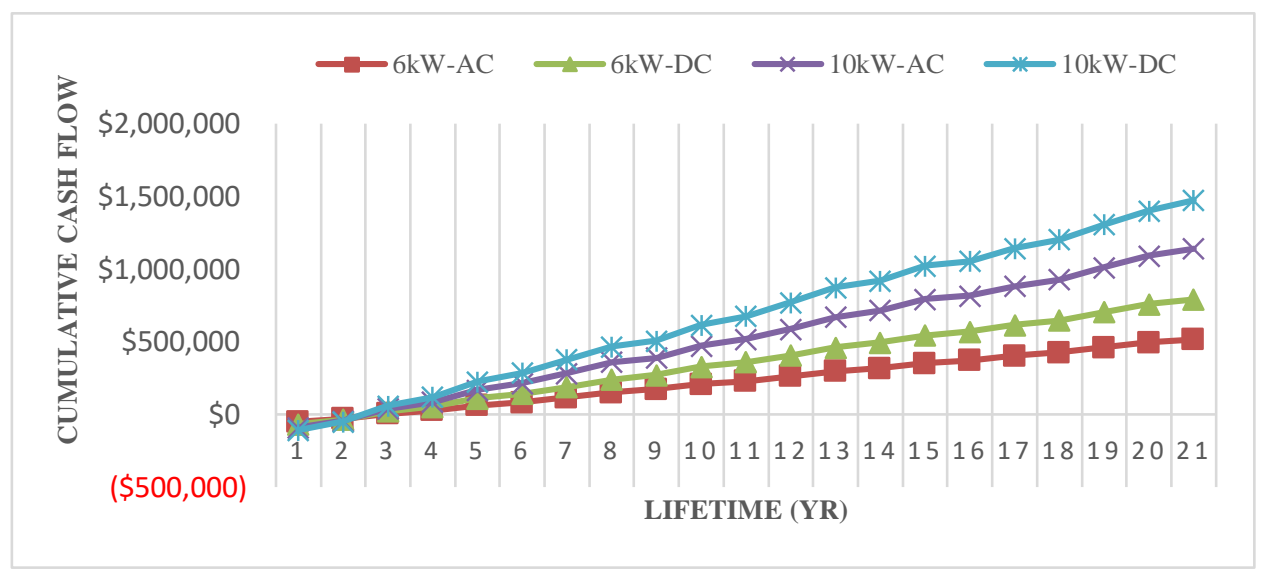

Figure 6. Graph of $P P$ of the four types of WECS system

\section{CONCLUSION}

The evaluation criteria are used in the $\operatorname{Sim}$ (equations 1, 2, 4, 5, 6, and 7) to optimisation, simulation and comparison. The results also show the most appropriate system in which investment can be a profitable investment. After loading the data in the homer, each configuration system is simulated to obtain the optimal results. The best configuration is an arrangement by total NPC value, it is an economic measure to determine whether a system is feasible or not, and its value is as low as possible. One of the most useful system features is that the configuration must have a lower $N P C$. The results show us the second criterion is $C O E$, where the homer calculates $C O E$ and the value is as low as possible. Therefore, an important criterion is $N P V$ and is considered one of the most important criteria for assessing the economics of any project. If the $N P V$ is a large value, it means that the system is good and therefore, the system chosen has a good future in terms of investment to achieve the best profitability. The fourth criterion is the IRR. If the value of IRR is large, 
the system means the best. Table 4 shows that the IRR value of WECS (10kW-DC) is the highest $(91.8 \%)$ compared to other types of WECS, and is a positive value for achieving the best profitability.

Finally, the fifth criterion is the $P P$ required to recover the initial amount invested in an electrical power system. Before planning to build a project to invest or developing an existing plant, the lifetime of any energy system must be calculated before it can be built. When the $P P$ value is large, investors may be exposed to a loss of investment cost. From Table 4, it is clear that the minimum $P P$ is 1.22 for WECS $(10 \mathrm{~kW}-\mathrm{DC})$ with a recovery period of up to two years. Generally, the wind energy conversion system WECS (10kW-DC) was determined as the most useful and profitable optimum system as compared in the evaluation criteria among four different types of WECS. Where optimization and simulation helped determine the most economic viability.

\section{REFERENCES}

[1] D. Pardeshi and B. S. Surjan, "A novel approach for the designing of controller for the Wind Energy Conversion System," in 2016 International Conference on Electrical Power and Energy Systems (ICEPES), pp. 383-389, 2016.

[2] A. Nouh and F. Mohamed, "Wind energy conversion systems: Classifications and trends in application," in 20145 th International Renewable Energy Congress (IREC), pp. 1-6, 2014.

[3] A. K. Nayak and K. B. Mohanty, "Adequacy assessment of wind energy conversion system through simulating wind speed using weibull distribution," in 2017 National Power Electronics Conference (NPEC), pp. 102-105, 2017.

[4] W. Dinghui, X. Lili, and J. Zhicheng, "Fuzzy adaptive control for wind energy conversion system based on model reference," in 2009 Chinese Control and Decision Conference, pp. 1783-1787, 2009.

[5] J. Hussain and M. K. Mishra, "Adaptive MPPT control algorithm for small-scale wind energy conversion systems," in 2014 IEEE International Conference on Power Electronics, Drives and Energy Systems (PEDES), pp. 1-5, 2014.

[6] A. Tyagi, A. Verma, and A. Saxena, "Optimal economic dispatch considering wind energy conversion systems using Gray coded genetic algorithm," in 2015 Annual IEEE India Conference (INDICON), pp. 1-5, 2015.

[7] Y. Himri, S. Himri, and A. B. Stambouli, "Wind speed data analysis used in installation of wind energy conversion systems in Algeria," in IEEE PES T\&D 2010, pp. 1-5, 2010.

[8] J. M. Mauricio, A. E. León, A. GÓmez-ExpOsito, and J. A. Solsona, "An electrical approach to mechanical effort reduction in wind energy conversion systems," IEEE Transactions on Energy Conversion, vol. 23, pp. 1108-1110, 2008.

[9] M. Bayat and H. K. Karegar, "Predictive control of wind energy conversion system," in 2009 1st International Conference on the Developements in Renewable Energy Technology (ICDRET), pp. 1-5, 2009.

[10] F. Hachicha and L. Krichen, "Performance analysis of a wind energy conversion system based on a doubly-fed induction generator," in Eighth International Multi-Conference on Systems, Signals \& Devices, pp. 1-6, 2011.

[11] M. N. Nashed and M. N. Eskander, "Performance of DFIG in wind energy conversion systems with different types of rotor converters," in 2011 International Conference on Electrical Machines and Systems, pp. 1-6, 2011.

[12] S. Pati, S. Kar, K. B. Mohanty, and S. S. Dash, "Voltage profile improvement of a micro grid system using a DFIG based wind energy conversion system," in 2014 IEEE International Conference on Power Electronics, Drives and Energy Systems (PEDES), pp. 1-6, 2014.

[13] M. Ferdosian, H. Abdi, and A. Bazaei, "Improved dynamic performance of wind energy conversion system by UPFC," in 2013 IEEE International Conference on Industrial Technology (ICIT), pp. 545-550, 2013.

[14] A. Mesemanolis, C. Mademlis, and I. Kioskeridis, "High-efficiency control for a wind energy conversion system with induction generator," IEEE transactions on energy conversion, vol. 27, pp. 958-967, 2012.

[15] S. Salhi, N. Aouani, and S. Salhi, "LPV affine modeling, analysis and simulation of DFIG based Wind Energy Conversion System," in 2015 7th International Conference on Modelling, Identification and Control (ICMIC), pp. 1-7, 2015.

[16] H. Mohammed and C. O. Nwankpa, "Stochastic analysis and simulation of grid-connected wind energy conversion system," IEEE Transactions on Energy Conversion, vol. 15, pp. 85-90, 2000.

[17] M. Ruba and M. Radulescu, "Analysis of a grid-connected wind energy conversion system based on complex simulation program," in 2015 Tenth International Conference on Ecological Vehicles and Renewable Energies (EVER), pp. 1-6, 2015.

[18] A. Sallam, W. El-Khattam, and H. El-Salmawy, "Economic impact of Capacity Credit evaluation for Wind Energy Conversion Systems projects in Egypt," in 2016 Eighteenth International Middle East Power Systems Conference (MEPCON), pp. 664-669, 2016.

[19] R. Siddique, A. Al Faisal, M. A. H. Raihan, and T. H. Asif, "A theoretical analysis of controlling the speed of wind turbine and assemblage of solar system in the Wind Energy Conversion system," in 2013 International Conference on Power, Energy and Control (ICPEC), pp. 653-657, 2013.

[20] S. Mishra, Y. Mishra, and S. Vignesh, "Security constrained economic dispatch considering wind energy conversion systems," in 2011 IEEE Power and Energy Society General Meeting, pp. 1-8, 2011.

[21] J. Fulzele and S. Dutt, "Optimium planning of hybrid renewable energy system using HOMER," International Journal of Electrical and Computer Engineering, vol. 2, no. 1, p. 68-74, 2012.

[22] S. Salhi, N. Aouani, and S. Salhi, "LPV polytopic modelling and stability analysis of a DFIG for a wind energy conversion system based on LMI approach," in 2017 International Conference on Green Energy Conversion Systems (GECS), pp. 1-6, 2017. 
[23] HOMER Pro Microgrid Analysis Tool x64 3.12.5. Available online: https://www.homerenergy.com/ (Accessed on 18 January 2019).

[24] M. K. Abd, H. N. Abdullah, H. Sun, and S. Cheng, "Techno-economic Viability and Energy Conversion Analysis of RHES with Less Weight/Area," TELKOMNIKA, vol. 16, no. 5, pp. 2331-2341, 2018.

[25] Y. Liu and G. Yu, "Energy-based robust adaptive maximum power point tracking control of wind power conversion systems," in 2016 35th Chinese Control Conference (CCC), pp. 1024-1029, 2016.

[26] M. Jafari, M. Popat, and B. Wu, "Power factor control in a wind energy conversion system via synchronous generator excitation," Canadian Journal of Electrical and Computer Engineering, vol. 37, pp. 145-150, 2014.

[27] W. S. de Oliveira and A. J. Fernandes, "Economic feasibility applied to wind energy projects," International Journal of Emerging Sciences, vol. 1, pp. 659-683, 2011.

\section{BIOGRAPHIES OF AUTHORS}

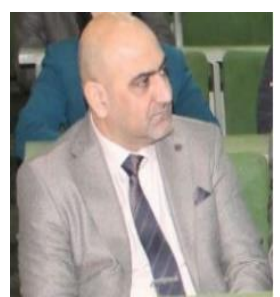

Mohammed Kdair Abd has been received the B.Sc. and M.Sc. degrees in Electrical Engineering from University of Technology, Baghdad, Iraq, in 2002 and 2005, respectively. $\mathrm{He}$ received $\mathrm{PhD}$ degree in Electrical Engineering from HUST, Wuhan, China in 2017. Since 2006, he has been a Lecturer with the Electrical Engineering Department, University of Technology, Baghdad, Iraq. His major research interest includes power system analysis and digital simulation, wind power integration, renewable energy technologies, distributed generator, FACTS, and power system operation and control. 